\title{
Assessment of satellite-based approach for the groundwater recharge estimation in arid regions
}

\author{
Nafiseh Salehi Siavashani ${ }^{1}$, Joaquin Jimenez-Martines ${ }^{2}$, Guillermo Vaquero ${ }^{3}$, FCO JAVIER \\ ELORZA TENREIRO ${ }^{4}$, Justin Sheffield ${ }^{5}$, lucila candela ${ }^{6}$, and Aleix Serrat-Capdevila ${ }^{7}$ \\ ${ }^{1}$ Universitat Politecnica de Catalunya \\ ${ }^{2}$ ETH Zürich \\ ${ }^{3}$ Fundación IMDEA Agua \\ ${ }^{4}$ Polytechnic University of Madrid Superior Technical School of Mines and Energy \\ ${ }^{5}$ University of Southampton \\ ${ }^{6}$ IMDEA \\ ${ }^{7}$ World Bank
}

May 11, 2020

\begin{abstract}
Estimation of aquifer recharge is a prerequisite for understanding groundwater systems and sustainable water resources management. In arid and semi-arid areas, where access to hydrologic data for groundwater studies is often limited with spatial and temporal inconsistencies, data collection is difficult. Therefore, in these regions satellite products of meteorological data series have recently turned into the most reliable alternative. This study presents a daily groundwater recharge estimation in the NW part of the Lake Chad Basin using VisualBALAN, a water-soil-plant distributed model, from two data sources (ground and satellite-based meteorological data) under non-irrigated and irrigated land. Precipitation and temperature data from ground-based gauge stations and the Multi-Source Weighted-Ensemble Precipitation product (MSWEP), was gathered for the years 2005-2014; average annual values were 283 and $417 \mathrm{~mm}$ and 30 and 29 for gauges and for MSWEP, respectively. The estimated mean annual aquifer recharge from precipitation equals 10.9 and $14.7 \mathrm{~mm} / \mathrm{yr}$, while in irrigated areas was 33 and $41 \mathrm{~mm} / \mathrm{yr}$, for ground and satellite-based data, respectively, being always slightly higher for the satellite estimates. Sensitivity analysis was performed to assess the dependency of input data in final recharge. Recharge estimates were mainly sensitive to soil type, soil parameters such as field capacity and wilting point, and to surface hydrology-related parameters such as curve number.
\end{abstract}

\section{Introduction}

Scarce precipitation, inter-annual dry periods, marked seasonal and spatial variability, and extreme rainfall events are the main features of arid and semi-arid zones that condition groundwater recharge (Noy-Meir, 1973; Lerner et al., 1990). Therefore, reliable precipitation and temperature data in these areas are of extreme importance for accurately assessing the soil water balance and groundwater recharge (Tolera et al., 2018; Kwarteng et al., 2009). Beyond the uncertainties inherent in available in-situ data, i.e., from weather ground-based stations, one of the main difficulties is data scarcity (Bhowmik and Costa, 2014; Dumolard, 2007; Wagner et al., 2012). Meteorological stations are generally scarce, unevenly distributed and may operate during short periods or have important gaps. This in turn can lead to problems if long-term values are required with only short data periods available (Lerner et al., 1990). Data and information are also often scattered among different agencies making difficult to obtain complete records of available data. Overall this results in information that is rarely suited to practical needs. To overcome this challenge, researchers have 
traditionally increased data availability using different statistical methods, especially filling gaps in time series and interpolating between data points, introducing uncertainties given the intermittency of rainfall and the large distances between observation points.

An alternative and complementary source of information is from satellite products (e.g., TRMM, CMORPH, TMPA) which can provide meteorological data series over large areas useful for multiple applications in hydrology (Habib et al., 2008; Mzirai et al., 2005; Velpuri et al., 2013; Sheffield et al., 2018). In arid and semi-arid zones, given the general scarcity of ground data, satellite products are a potentially useful tool for hydrological studies. Nevertheless, these data products are affected by uncertainties resulting from physical sensor limitations, limited space-time coverage and spatial resolution (Prigent, 2010; Knoche et al., 2014), which is especially relevant in these regions because of the high spatial and temporal variability of surface meteorology. A comparison with ground-based data as an indicator and estimation of uncertainty is necessary to understand the utility of such products, and much work has been done in this especially with regard to precipitation (e.g., Beck et al., 2017; Jiang et al., 2016; Lu et al., 2016; Nogueira et al., 2018; Haile et al., 2015). However, to date, no studies have compared the performance of these two data sources (ground-based and satellite) in hydrological studies for the quantification of groundwater recharge in particular.

Quantification of natural groundwater recharge is a basic prerequisite for efficient water resources management. Groundwater recharge is a complex function that results from the coupling of several factors. The factors controlling the amount and type of aquifer recharge include: precipitation (volume, intensity, duration), topography, vegetation (cropping pattern, rooting depth) and evapotranspiration, soil and subsoil types, flow mechanisms in the unsaturated zone, bedrock geology, and available groundwater storage (Scanlon et al., 2002). Various reviews on the quantification of aquifer recharge have been conducted in the past, focusing primarily on arid and semi-arid regions (Scanlon et al., 2006) and methods (de Vries and Simmers, 2002; Scanlon et al., 2002; Walker et al., 2019). While the spatio-temporal distribution of precipitation is the most critical factor (Wu et al, 1996), the chosen method can make recharge estimation vary greatly (Leduc et al., 2000).

The current work focuses on the Lake Chad Basin, an arid region in which the surface water supply is insufficient to fulfil the needs of the local population, and groundwater therefore provides the main water supply for urban and rural areas. Over the last 40 years, much attention has been given for improving recharge estimation in this area. These have mainly included isotopic studies (Fontes et al., 1970; Ketchemen, 1992; Njitchoua and Ngounou Ngatcha, 1997; Edmunds et al., 1998; Goes, 1999; Leduc et al., 2000; Djoret and Travi, 2001; Ngounou Ngatcha et al., 2001; Gaultier, 2004; Goni, 2006; Ngounou Ngatcha et al., 2007a; Tewolde et al., 2019) and mathematical modelling (Babama'aji et al., 2012). Some studies have used remote sensing data for investigating groundwater processes (e.g., Meteosat thermal data) combined with hydrogeological data (Leblanc et al., 2003, 2007), or the spatiotemporal variability of the hydrological parameters of the Lake Chad basin (Buma et al., 2016), but natural recharge for the area, which is highly variable over spatial and temporal scales, still remains uncertain.

The main objective of this work is to explore changes in groundwater recharge, i.e., performance evaluation of data input, in an arid area based on a soil-water-plant distributed model from two data sources: i) available ground-based meteorological data from local stations, and from ii) satellite-based meteorological data. A detailed comparison and sensitivity analysis of the model parameters is performed to evaluate the reliability and uncertainty of the estimated recharge values from the two data sources.

\section{Study area. The Lake Chad basin}

The study area is located in the north-west part of the Lake Chad basin system, extending over an area of about 155,000 $\mathrm{km}^{2}$ of the basin in Chad, Niger and Nigeria (Figure 1). The region is categorized as arid to semi-arid, having the major rainfall season between April and September. Average annual precipitation varies from 20 to $600 \mathrm{~mm}$, daily temperatures between 8 and 45 , and mean annual potential evaporation above $2000 \mathrm{~mm}$ (Mahmood and Jia, 2018; LCBC-GIZ, 2016). A succession of dry periods during the last 100 years has led to a severe depletion of the lake area from $22,000 \mathrm{~km}^{2}$ to $8,000 \mathrm{~km}^{2}$ currently, decreasing 
drastically the extension of the seasonally inundated river plains. The associated impact on infiltration and groundwater recharge remains unknown, but it is likely important.

The region is relatively flat with a gentle slope (10\%) from the highlands in the NW towards the SE. The land cover is grassland (65\%), bare land (20\%), sparse vegetation (5\%), and croplands (rain fed and irrigated, $10 \%$ ) (LCBC-GIZ, 2016). Irrigation of crops (mainly peppers and millet), covering approximately 21,295 $\mathrm{km}^{2}$, is done by combining groundwater and surface water.

At regional scale, the geology of the study area consists of materials from the Precambrian, Mesozoic (Cretaceous), and Plio-Quaternary (Burke, 1976; Schneider and Wolff, 1992; BRGM, 1994; Schneider, 1989). The Cretaceous material is predominantly continental, and that along with Miocene formations is known as the Continental Terminal (Kilian, 1931). The Plio-Quaternary deposits comprise fluvio-lacustrine, fluvio-deltaic, and aeolian material. Outcrops of igneous rocks complete the geology of the region (Ganwa et al., 2009; Vicat et al., 2002). From the hydrogeological point of view, three aquifers are distinguished in the area (Schneider and Wolff, 1992): Quaternary, Lower Pliocene and Continental Terminal, both mainly confined. Only the groundwater recharge to the Quaternary unconfined aquifer is the objective of this research (Figure 1).

\section{Methodology}

A soil water balance modelling approach was used to estimate groundwater recharge to the Quaternary unconfined aquifer for the 2005-2014 period. Two sources of meteorological data needed were used: i) ground-based data from selected local meteorological stations, and ii) satellite-based data for the same timeperiod and geographic location (coordinates) of field stations. The analysis focuses on understanding how the different data sources affect the amount of recharge, given the highly non-linear behavior of the process of recharge through the soil. Statistical relationships between precipitation and temperature of the two data sources (ground and satellite estimates) were evaluated by visual inspection and basic statistical measures. A sensitivity analysis of soil parameters to assess the reliability and uncertainty on recharge estimation for the non-irrigated area was also carried out.

\subsection{Soil water balance model description}

Aquifer recharge was calculated using VisualBALAN v.2.0 (Samper et al., 2005), a computer code suitable for long-term simulation of water balance in the soil, vadose zone and aquifer. It has been successfully applied in different areas (e.g., Candela et al., 2016; Jimenez-Martinez et al., 2010, among many others). Among the many advantages of using VisualBALAN, the use of generally available input data, which can be estimated with reasonable accuracy, makes its application straightforward.

The code is divided into three sub-models taking into account processes in i) the upper part of the soil (root zone), solving the critical interactions of the soil-plant-atmosphere continuum, ii) the vadose or unsaturated zone (below the root zone), and iii) the saturated zone (aquifer). A schematic representation of the water balance components is represented in Figure 2. Precipitation $(P)$ and irrigation $(I)$ is distributed between surface runoff and infiltration. A part of infiltration comes back to the atmosphere by evapotranspiration $(E T a)$, another part increases the water content in the soil and the remaining part contributes to potential recharge, which is the input of water to the vadose zone. Inside of this zone, the water can flow horizontally, as interflow, or it can percolate vertically to the aquifer $(R)$ (Figure 2). The potential diffuse recharge to is estimated assuming that the soil is homogeneous and isotropic.

A comprehensive explanation of the conceptual model and corresponding parameters can be found in Jimenez-Martinez et al. (2010). For this particular case, processes in the saturated zone have been obviated, assuming that the infiltrated water reaching a depth beyond the action of the roots and evaporation turns into percolation to the aquifer.

\subsection{Climatic data sets}

For the 2005-2014 period, daily temperature $\left({ }^{\circ} \mathrm{C}\right)$ and precipitation $(\mathrm{mm})$ recorded time series from five 
ground-based stations in the study area and their satellite estimates constituted the model meteorological data. The exploratory analysis of the data involved analysis using graphs and basic statistical measures.

\subsubsection{Ground data}

Ground-based time series were directly compiled from the Trans-African Hydro-Meteorological Observatory, TAHMO platform (http://tahmo.org/african-climate-data). Data from five local meteorological stations (Diffa, Goure, Maine, Nguigmi, and Zinder, Figure 1) were used. Over the historical data record (1973-2018), the study period (2005-2014) was chosen as the one presenting the least gaps $(\leq 20 \%)$ in the time series of precipitation and temperature. The nine year's length of the dataset enables the capture of the variability of daily precipitation and temperature in the region.

Missing value analysis and homogeneity tests were conducted for the available precipitation dataset. To fill the missing data, Inverse Distance Weighting based on four rain-gauge stations in the vicinity of the station analyzed was applied (Lam, 1983). The interpolation is based on the Thiessen Polygon method.

\subsubsection{Satellite-based data}

The Multi-Source Weighted-Ensemble Precipitation (MSWEP), a new fully global historic precipitation dataset, was selected as the source for the satellite-based data, based on the data availability for the region of interest. MSWEP takes advantage of the complementary strengths of gauge, satellite, and reanalysis-based data, providing reliable precipitation estimates (Beck et al., 2019). The datasets, including daily gauge corrections and systematic terrestrial precipitation biases (e.g., from orographic enhancement of precipitation), are corrected using river discharge observations. The provided gridded precipitation datasets have been validated using observations and by comparison with other satellite-based products (Beck et al., 2017, 2019b). The gridded precipitation daily estimates for the study period (2005-2014) were obtained from the Lake Chad Basin Flood and Drought Monitor System (CHAD-FDM).

\subsection{Model setup and sensitivity analysis}

The topography of the land surface (elevation and slope) was obtained from a $30 \times 30 \mathrm{~m}$ DEM (USGS Global Data Explorer, GDEx). Land use and land cover data were provided by The European Space Agency (ESA). Different land uses occur in the region, including forest (e.g.,acacias), urban, and non-irrigated (e.g., millet, sorghum, maize and rice) and irrigated (peppers) crops (LCBC-IRD, 2016). Soil related information (e.g. , clay and silt content, and hydrologic soil group) was compiled from the European Soil Data Centre (Jones et al., 2013) and literature. A homogeneous loamy sand was considered as main soil type, according to the USDA Soil Textural Classification (LCBC-IRD, 2016; Gaultier, 2004). Four base maps were produced, corresponding to climate, land cover, aquifers and soil attributes, and were overlaid to create the final base map using GIS tools.

Surface components, daily irrigation $(I)$ and precipitation $(P)$ rates, are expressed as an equivalent water depth $(\mathrm{mm})$. Irrigation of crops is done by combining groundwater and surface water; crop water needs were derived from Allen et al. (1998). Daily potential evapotranspiration (ETp ) is computed by the Thornthwaite method (Thornthwaite and Holzman, 1939), using available temperature from ground stations or satellite from MSWEP. Soil-aquifer parameters (soil depth, porosity, field capacity, wilting point, hydraulic conductivity, storage coefficient) and the vegetation parameters (height and interception coefficient) complete the main inputs to the system.

Quantifying the effect of uncertainties on the recharge estimates, depending on the data source used to define the boundary condition, i.e., ground or satellite-based, requires also knowledge of the model parameters and of their statistical variability and correlation structure. It is possible to evaluate the importance of the parameter uncertainties on recharge as the objective function by means of sensitivity analysis (JiménezMartínez et al., 2010). A series of simulations were performed on individual model parameters by a given amount of perturbation ( $\pm 25 \%$ of original data) and by estimating the groundwater recharge for both sources of precipitation and temperature used to define the boundary condition. 


\section{Results and discussion}

\subsection{Ground versus satellite-based data sets}

Daily temperature $\left({ }^{\circ} \mathrm{C}\right)$ and precipitation $(\mathrm{mm})$ from ground stations (TAHMO) and satellite (MSWEP) are shown in Figure 3. Three out of five ground-based stations (Figure 1), Nguigmi, Zinder and Maine shown complete daily temperature and precipitation records, while Goure and Diffa presented $3.3 \%$ and $2.5 \%$ missing values for the selected time period (2005-2014), respectively. Occasionally, one station may have a larger amount of precipitation during one particular year than the nearby stations when a large percentage of the annual precipitation falls in one or two storms. The temperature values for both time series, ranging between 15 and $40{ }^{\circ} \mathrm{C}$, show a close agreement at seasonal scale.

In general, the satellite data overestimate precipitation (Figure 4), except for two heavy (extreme) rainfall events recorded in local weather stations (August 2008 and August 2011). Storm effect has been already reported by several authors (McCollum et al., 1999; Nogueira et al., 2018; Young et al., 2014). The explanation could be due to the lack of accounting for cloud microphysical processes in the satellite based data, and the moisture distribution of the environment (McCollum et al., 1999). In particular, the overestimation by infrared-based satellite retrieval algorithms (which contribute to MSWEP) is attributed to no raining cirrus with cold cloud-top temperatures (Young et al., 2014).

Annual precipitation from the ground-stations and satellite estimates is plotted in Figure 5a,b; computed annual precipitation as the cumulative deviation from the mean to identify the possible presence of trends is in Figure 5c,d. Visual observation indicates that wet and dry conditions appear to be different for the two data sources. The wettest and driest years of the regional mean rainfall series occurred in 2008 (600 $\mathrm{mm})$ and $2006(10 \mathrm{~mm})$ for the ground data, and in $2006(920 \mathrm{~mm})$ and $2011(200 \mathrm{~mm})$ for the satellite data, respectively. However, and according to the analysis, the presence of trends has not be identified.

To assess the dependence between the two data sets, a regression analysis was performed, and the goodnessof fit assessed by the coefficient of determination $\left(\mathrm{R}^{2}\right)$ (Figure 6). At daily basis, lack of correlation $\left(\mathrm{R}^{2}=\right.$ 0.06 ) has been found between ground and satellite-based data. By changing from daily to monthly scale and focusing on months with relatively high precipitation (July-August-September), the scatter is reduced while the $\mathrm{R}^{2}$ increases, indicating that both platforms record similar rainfall amounts at the monthly scale.

\subsection{Recharge estimation}

Two types of groundwater recharge are distinguished in the study area: (1) direct infiltration from precipitation, and (2) aquifer recharge in irrigated areas, resulting from the combination of precipitation and irrigation. The estimated mean annual recharge from precipitation equals 10.9 and $14.7 \mathrm{~mm} / \mathrm{yr}$ for ground and satellite-based data, respectively (Table 1). Although apparently annual recharge and total recharge for the studied period from the satellite-based data are similar when compared with results from ground stations, they are $46 \%$ higher. At daily scale, the highest rates of recharge from the satellite-based data are primarily due to more abundant precipitation and lower temperature, resulting in a much higher total aquifer recharge (Table 1). These differences are accentuated in extremely dry and wet years such as 2006 and 2011. For the ground-based recharge values, similar ones have been obtained from an established numerical flow model in the Lake Chad Basin for the same period (TWB, 2019). These values are similar to those of Berger (1992), Edmunds (1998) and Ngounou Ngatcha (2009), who estimated 15-50 mm/yr in the sand dunes. This is also in agreement with aquifer recharge estimations (1-30\% of the precipitation) in semi-arid and arid regions around the world (Carter et al., 1994).

The computed mean annual aquifer recharge in irrigated areas was 33.5 and $41.6 \mathrm{~mm} / \mathrm{yr}$ for ground and satellite-based data, respectively (Table 1). Previous studies in irrigated zones and for semi-arid climates show that irrigation return may vary between $1 \%$ and $25 \%$ of the applied water, with the average being $15 \%$ (Scanlon et al., 2006). The values obtained are within the first half of this range (1-13\%). Precipitation from the satellite-based data is $32 \%$ higher than values measured at the ground stations, nevertheless, the differences in recharge were lower $(\sim 23 \%)$, indicating the non-linearity of the recharge processes. Although 
precipitation, and therefore $P+I$, is higher from the satellite-based data, actual evapotranspiration is almost double compared to the values estimated from the ground data (Figure 7). Note that in areas where the water table is close to the ground surface, the water table can provide an additional source of water for evapotranspiration (Smerdon et al., 2008).

Daily recharge calculation for the non-irrigated and irrigated areas for the year 2012 from ground stations and satellite-based data are shown in figure 8. The groundwater recharge in non-irrigated and irrigated areas takes mainly place following the rainfall period, between June and October, and recharge does not occur during the rest of the hydrologic year. Recharge response to precipitation events (non-irrigated) is highly variable (Figure 8a,b), more or less independent of the amount of rainfall and the changes over time, but highly dependent on soil moisture conditions; for the ground-based calculations, it is only produced after an important rainfall episode $(60 \mathrm{~mm}$, Figure 8a). Irrigation dose and its frequency of application are the most important parameters controlling recharge (Figure 8c, d). Cyclical variability, as a response of irrigation application, was observed; the effects of rainfall events were less influential in recharge from irrigated areas than in the non-irrigated counterpart.

\subsection{Sensitivity analysis}

A series of simulations were performed by perturbing the following model parameters: field capacity, wilting point, soil thickness, soil porosity, soil hydraulic conductivity, curve number and initial conditions (initial soil water content, initial water level) to evaluate the impact on the aquifer recharge estimates. The initial parameters considered were: field capacity, $0.1\left(\mathrm{~m}^{3} / \mathrm{m}^{3}\right)$; wilting point $0.05\left(\mathrm{~m}^{3} / \mathrm{m}^{3}\right)$; soil thickness, $6 \mathrm{~m}$; soil total porosity, 0.42; soil hydraulic conductivity $210^{-5}(\mathrm{~m} / \mathrm{s})$; and curve number, 77 . The boundary conditions (temperature, precipitation and irrigation) were held at their baseline values. The effect of the perturbations on the estimated recharge relative to the baseline simulation was then evaluated (Figure 9).

The results show for both ground and satellite-based data that only changes or uncertainties in field capacity, wilting point, and curve number lead to significant changes in the aquifer recharge estimations (Figure 9). Although the changes in the mean annual recharge due to perturbations in wilting point and field capacity is linear and quasi-linear, respectively, the magnitude is not the same for ground stations and satellite-based data. For example, an increase of $25 \%$ in wilting point leads to $1.6 \%$ increase of recharge for ground and $4.4 \%$ for satellite data. On the other hand, the perturbation of the curve number results in a different magnitude of recharge and differs depending on the magnitude of the perturbation between ground stations and satellitebased data. Changes in porosity (soil thickness and hydraulic conductivity, these two not shown here) have much less impact on the computed recharge.

\section{Conclusions}

The most important source of water to aquifer systems corresponds to recharge from precipitation. Reliable aquifer recharge estimation is crucial to assess and manage groundwater resources and its role will become increasingly important as demand increases and the impacts of climate change and variability become critical. Data scarcity and the non-linearity of recharge processes are the most important obstacles for recharge estimation in arid and semi-arid areas. Precise ground-based daily data of temperature and rainfall is probably the most difficult data to obtain. The use of remote sensing data sources can facilitate this by providing continuous estimates in time and space as presented here. However, the use of these two data sources (satellite and ground observations) can lead to different recharge estimates. A comparative analysis of the computed groundwater recharge estimates can help to establish a range of possible real values, beyond the uncertainty related to the model parameters considered.

In this case study, NW of Lake Chad basin, the effect of the ground-based and satellite precipitation amount is clearly reflected in the calculated total recharge. Aquifer recharge is predominantly concentrated during short periods of time and controlled by climatic factors such as precipitation, evapotranspiration and applied irrigation. At annual scales, for both irrigated and non-irrigated scenarios, important cyclical variability is observed (rainy season from June-October) as a response of intra-annual natural climate temporal variation and the few intense rainfall events. The observed difference of recharge between ground-based and satellite 
products $(23 \%)$ reflects the different precipitation input from both platforms along time. As recharge is highly dependent on changes of soil moisture condition over time, the extended distribution of precipitation along time from satellite implies higher soil water content and greater contribution to groundwater recharge. When irrigation is applied, it mainly dominates final recharge. Irrigation may simultaneously abstract water from the recharged source or surface water, while creating new diffuse recharge accounting for a substantial portion of recharge. Recharge sensitivity to some soil parameters was shown to be variable.

The groundwater recharge is not a linear process, more precipitation does not mean a proportional increase in recharge, since the rate of evapotranspiration will also rise with more water availability. In addition, the spatio-temporal variability in irrigation and spatial variability of soil parameters further increases the uncertainty in estimating recharge. Accurate recharge estimates are essential for sustainable long-term water resources management in the Lake Chad Basin region, especially in the very arid zones, where groundwater is the main water resource. If groundwater exploitation far exceeds recharge inflows, groundwater will mostly come from aquifer storage, a situation leading to aquifer depletion.

Better understanding of recharge mechanisms will elucidate aspects related to the sustainability of groundwater exploitation rates spatially across the basin. This fact is especially important if future land use changes and new agricultural developments may require increased surface water and groundwater withdrawal.

\section{Acknowledgements}

This study was partially funded by the Cooperation in International Waters in Africa (CIWA) Program of the World Bank, as part of a broader effort on groundwater resources in the Lake Chad Basin. The support from the LCBC is gratefully acknowledged.

\section{Data Availability statement}

The data that support the findings of this study are available from the corresponding author upon reasonable request.

\section{References}

Allen, R. G., Pereira, L. S., Raes, D., \& Smith, M., 1998. Crop evapotranspiration-Guidelines for computing crop water requirements-FAO Irrigation and drainage paper 56. Fao, Rome, 300 (9), D05109.

Babama'aji, R. A., 2013. Impacts of precipitation, land use land cover and soil type on the water balance of Lake Chad, PhD thesis, University of Missouri-Kansas City.

Beck, H. E., Pan, M., Roy, T., Weedon, G. P., Pappenberger, F., van Dijk, A. I. J. M., Huffman, G. J., Adler, R. F., and Wood, E. F., 2019. Daily evaluation of 26 precipitation datasets using Stage-IV gauge-radar data for the CONUS.Hydrology and Earth System Sciences, 23(1), 207-224.

Beck, H. E., van Dijk, A. I. J. M., Levizzani, V., Schellekens, J., Miralles, D. G., Martens, B., De Roo, A., 2017. MSWEP: 3-hourly $0.25^{\circ}$ global gridded precipitation (1979-2015) by merging gauge, satellite, and reanalysis data. Hydrology and Earth System Sciences , 21(1), 589-615.

Beck, H. E., Wood, E. F., Pan, M., Fisher, C. K., Miralles, D. G., van Dijk, A. I., Mc Vicar, T., Adler, R. F., 2018. MSWEP V2 global 3-hourly $0.1^{\circ}$ precipitation: methodology and quantitative assessment.Bulletin of the American Meteorological Society, doi: 10.1175/BAMS-D-17-0138.1.

Berger, D. L., 1992. Groundwater recharge through Actwe sand dunes in northwestern Nevada, Water Resources Bulletin, American Water Resources Association, 28, 5.

Bhowmik, A. K., Costa, A. C., 2014. Data scarcity or low representativeness?: What hinders accuracy and precision of spatial interpolation of climate data?, Huerta, Schade, Granell (Eds.): Connecting a digital Europe through location and place. Proceedings of the AGILE', International conference on Geographic Information Science, Castellón, June, 3-6. ISBN: 978-90-816960-4-3. 
BRGM, 1994. Actualisation des connaissances sur les ressources en eau souterraines de la République du Tchad (deuxième partie): Synthèse des données hydrogéologiques et carte a 1/1.500.000; Orleans, France.

Buma, W. G., Lee, S., Seo, J. Y., 2016. Hydrological evaluation of Lake Chad Basin using space borne and hydrological model observations. Water , 8, 205, doi:10.3390/w8050205.

Burke, K., 1976. The Chad Basin: An intra-continental basin. Tectonophysics, 36, 192-206.

Carter, R. C., Morgulis, E. D., Dottridge, J., Agbo, J. U., 1994. Groundwater modelling with limited data: a case study in a semi-arid dunefield of northeast Nigeria. Quarterly Journal of Engineering Geology and Hydrogeology, 27, S85-S94.

de Vries, J. J., Simmers, I., 2002. Groundwater recharge: an overview of processes and challenges. Hydrogeology Journal , 10, 5-17.

Djoret, D., Travi, Y., 2001. Groundwater vulnerability and recharge or paleorecharge in the southeastern Chad basin, Chari Baguirmi aquifer. In: Isotope techniques in water resource investigations in arid and semi-arid regions, IAEA-TECDOC-1207, 33-40.

Dumolard, P., Dobesch, H., Dyras, I., 2007. Spatial interpolation for climate data. The use of GIS in climatology and meteorology, 57-70.

Edmunds, W., Fellman, E., Goni, I., McNeill, G., Harkness, D. D., 1998. Groundwater, palaeoclimate and palaeorecharge in the southwest Chad Basin, Borno State, Nigeria, journal of Isotope Techniques in the Study of Environmental Change (IAEA-SM-349).

Fontes, J-Ch., Gonfiantini, R., Roche, M. A., 1970. Deutérium et oxygène-18 dans les eaux du lac Tchad, Isotope Hydrology, Proc. Symp. Vienna, 387p.

Ganwa, A. A., Doumnang M. J. C., Lagmet, C., 2009. Pétrographie et données structurales sur les dômes rhyolitiques du sud du Lac Tchad (Dandi-Hadjer El Hamis): relation avec la Ligne du Cameroun. Rev. Cames $, 8,80-85$.

Gaultier, G., 2004. Recharge et paléorecharge d'une nappe libre en milieu sahélien (Niger Oriental): approches géochimique et hydrodynamique. Thèse Doctorat. Université Paris Sud, Orsay, 179p.

Goes, B. J. M., 1999. Estimate of shallow groundwater recharge in the Hadejia-Nguru Wetlands, semi-arid northeastern Nigeria.Hydrogeology Journal , 7, 294-304.

Goni, I., 2006. Tracing stable isotope values from meteoric water to groundwater in the southwestern part of the Chad basin. Hydrogeology Journal , 14(5), 742-752.

Habib, E.; Aduvala, A.V.; Meselhe, E.A. 2008. Analysis of radar-rainfall error characteristics and implications for streamflow simulation uncertainty. Hydrology Science Journal , 53, 568-587.

Haile, A. T., Yana, F., Habib, E., 2015. Accuracy of the CMORPH satellite-rainfall product over Lake Tana Basin in Eastern Africa.Atmospheric Research , 163, 177-187.

Jiang, P., Yu, Z., Gautam, M. R., 2016. The spatiotemporal characteristics of extreme precipitation events in the Western United States. Water Resource Management, 30, 4807. doi: 10.1007/s11269-016-1454-z.

Jiang, S., Zhou, M., Ren, L. L., Cheng, X., Zhang, P., 2016. Evaluation of latest TMPA and CMORPH satellite precipitation products over Yellow River Basin. Water Science and Engineering , 9, 2, 87-96.

Jiménez-Martínez, J., Candela, L., Molinero, J., Tamoh, K., 2010. Groundwater recharge in irrigated semiarid areas: quantitative hydrological modelling and sensitivity analysis. Hydrogeology Journal , 18, 1811-1824.

Jones, A., Breuning-Madsen, H., Brossard, M., Dampha, A., Deckers, J., Dewitte, O., Gallali, T., Hallett, S., Jones, R., Kilasara, M., Le Roux, P., 2013. Soil atlas of Africa . European Commission. 
Ketchemen, B., 1992. Etude hydrogéologique du Grand Yaéré (Extrême Nord du Cameroun). Synthèse hydrogéologique et étude de la recharge par les isotopes de l'environnement. Thèse de Doctorat 3ème cycle, Université Cheikh Anta Diop Dakar, Sénégal.

Kilian, C., 1931. Des principaux complexes continentaux du Sahara.C R. S. Soc. Géol. France, 9, 109-111.

Knoche, M., Fischer, C., Pohl, E., Krause'P., Merz, R., 2014. Combined uncertainty of hydrological model complexity and satellite-based forcing data evaluated in two data-scarce semi-arid catchments in Ethiopia. Journal of Hydrology , 519, 2049-2066.

Kwarteng, A. Y., Dorvlo, A. S., Kumar, V., 2009. Analysis of a 27-year rainfall data (1977-2003) in the Sultanate of Oman. International Journal of Climatology, 29, 605-617, doi: 10.1002/joc.1727.

Lam, N., 1983. Spatial interpolation methods: a review. American Cartographer, 10, 129-149.

LCBC-GIZ, 2016. Report on the state of the Lake Chad basin ecosystem, Deutsche Gesellschaft fur Internationale Zusammenarbeit (GIZ) GmbH. Bonn., 233 p.

LCBC-IRD, 2016. Report on Part 2: reliability enhancement / complement to the existing model. Institut de Recherche pour le Développement (IRD), France, 77 p.

Leblanc, M., Leduc, C., Razack, M., Lemoalle, J., Dagorne, D., Mofor, L., 2003. Applications of remote sensing and GIS for groundwater modelling of large semiarid areas: Example of the Lake Chad Basin, Africa. IAHS Publ., 278, 186-192.

Leblanc, M., 2002. The use of remote sensing and GIS for water resources management of large semi-arid regions: a case study of the Lake Chad Basin, Africa. PhD Thesis, School of Technology, University of Glamorgan, UK and School of Geosciences, Poitiers University, France.

Leblanc, M., Favreau, G., Tweed, S., Leduc, C., Razack, M., Mofor, L., 2007. Remote sensing for ground water modelling in large semiarid areas: Lake Chad basin, Africa. Hydrogeology Journal , 15, 97-100.

Leduc, C., Sabljak, S., Taupinc, J. D., Marlinb, C., Favreaua, G., 2000. Estimation de la recharge de la nappe quaternaire dans le Nord-Ouest du bassin du lac Tchad (Niger oriental) à partir de mesures isotopiques. $C$. R. Acad. Sci. Paris, Sciences de la Terre et des planètes / Earth and Planetary Sciences, 330, 355-361.

Lerner, D. N., Issar, A. S., and Simmers, I., 1990. Groundwater recharge-a guide to understanding and estimating natural recharge: International Association of Hydrogeologists, International Contributions to Hydrogeology, 8, 147 p.

Lu, C. H., Sun, Y., Wan, H., 2016. Anthropogenic influence on the frequency of extreme temperatures in China. Geophysiscal Research Letter , 43, 6511-6518.

Lu', X., Wang, L., Pan, M., Kaseke, K. F., Li, B., 2016. A multi-scale analysis of Namibian rainfall over the recent decade- comparing TMPA satellite estimates and ground observations. Journal of Hydrology: Regional Studies , 8, 59-68.

Mahmood, R., Jia, S., 2018. Analysis of causes of decreasing inflow to the Lake Chad due to climate variability and human activities.Hydrology and Earth System Sciences Discussion, doi: 10.5194/hess, 2018-139.

McCollum, J. R., Gruber, A., Ba, M. B., 1999. Discrepancy between gauges and satellite estimates of rainfall in Equatorial Africa. Journal of Applied Meteorology , 39, 666-679.

McElwee, C.D., 1978. Sensitivity of groundwater models with respect to variations in transmissivity and storage. Water Resources Research , 14(3), 451-459.

Misstear, B.D.R., 2000. Groundwater recharge assessment: A key component of river basin management, National Hydrology Seminar. 
Mzirai, O. B., Tumbo, S. D., Bwana, T., Hatibu, N., Rwehumbiza, F. B., Gowing, J. W., 2005. Evaluation of simulator of missing weather data (SMWD) required in simulation of agro hydrological modelling in the catchment and basin level: Case of the Parched-Thirst and Marksim Model. In Proceedings of the International Water Management Institute Conference Papers, Santiago, Chile, 15-17 March.

Ngounou Ngatcha, B., Mudry, J., Aranyossy, J.F., Naah, E., Sarrot-Reynauld, J., 2007a. Apport de la géologie, de l'hydrogéologie et des isotopes de l'environnement à la connaissance des «nappes en creux» du Grand Yaéré (Nord Cameroun). Journal of Water Science/Revue des Sciences de l'eau , 20(1), 29-43.

Ngounou Ngatcha, B., Mudry, J., Sarrot-Reynauld, J., 2007b. Groundwater recharge from rainfall in the southern border of Lake Chad in Cameroon. World Applied Sciences Journal, 2(2), 125-131.

Ngounou Ngatcha, B., Mudry, J., Wakponou, A., Ekodeck, G. E., Njitchoua, R., Sarrot-Reynauld, J., 2001. Le cordon sableux Limani-Yagoua (Nord Cameroun) et son rôle hydraulique. Journal of African Earth Sciences , 32(4), 889-898.

Ngounou Ngatcha B., 2009. Water resources protection in the Lake Chad basin in the changing environment. European Water , 25/26, 3-12.

Njitchoua, R., Ngounou Ngatcha, B., 1997. Hydrogeochemistry and environmental isotopic investigations of the North Diamaré plain, Extreme-North of Cameroon, Journal of African Earth Sciences , 25(2), 307-316.

Nogueira, S. M., Moreira, M. A., Volpato, M. M., 2018. Evaluating Precipitation Estimates from Eta, TRMM and CHRIPS Data in the South-Southeast Region of Minas Gerais State-Brazil. Remote Sensing , 10(2) 313, doi: $10.3390 / \mathrm{rs} 10020313$.

Nogueira, S. M. C., Moreira, M. A., Lordelo Volpato, M. M., 2018. Evaluating Precipitation Estimates from ETa, TRMM and CHRIPS Data in the South-Southeast Region of Minas Gerais State-Brazil. Remote Sensing , 10, 313.

Noy-Meir, I., 1973. Desert ecosystems: environment and producers. Annual Review of Ecology and Systematics , 4, 25-51.

Prigent, C., 2010. Precipitation retrieval from space: An overview.Comptes Rendus Geosciences , 342(4), 380-389.

Samper, J., Huguet L. 1., Ares J., García-Vera, M. A., 2005. User's guide VisualBALAN v.2.0: código interactivo para la realización de balances hidrológicos y la estimación de la recarga [VisualBALAN v.2.0: interactive code to establish water balance and aquifer recharge]. Civil Engineering School of A Coruña, A Coruña, Spain, 150 p.

Scanlon, B. R., Healy, R. W., Cook, P. G., 2002. Choosing appropriate techniques for quantifying groundwater recharge. Hydrogeology Journal , 10, 18-39.

Scanlon, B. R., Keese, K. E., Flint, A. L., Flint, L. E., Gaye, C. B., Edmunds, W., Simmers, I., 2006. Global synthesis of groundwater recharge in semiarid and arid regions. Hydrological Processes , 20, 3335-3370.

Schneider, J., Wolff, J., 1992. Carte géologique et cartes hydrogéologiques à 1:1.500,000 de la République du Tchad. Mémoire Explicatif, Tech. Rep. BRGM 209, BRGM, Orléans.

Schneider, J. L., 1989. Géologie et hydrogéologie de la Républic du Tchad. PhD. Thesis presented at the University of Avignon, France, 3 vol.

Sheffield, J., Wood, E.F., Pan, M., Beck, H., Coccia, G., Serrat-Capdevila, A., Verbist, K., 2018. Satellite remote sensing for water resources management: potential for supporting sustainable development in datapoor regions, Water Resources Research , 54, doi: 10.1029/2017WR022437.

Smerdon, B., Mendoza, C., Devito, K., 2008. Influence of sub humid climate and water table depth on groundwater recharge in shallow outwash aquifers. Water Resources Research , 44, W08427, 
doi:10.1029/2007WR005950.

Stephenson, G. R., Zuzel, J. F., 1981. Groundwater recharge characteristics in a semi-arid environment of southwest Idaho. Journal of Hydrology, 53, 213-227.

Tamiru Haile, A., Yan, F., Habi, E., 2015. Accuracy of the CMORPH satellite-rainfall product over Lake Tana Basin in Eastern Africa.Atmospheric Research , 163(15), 177-187.

Tewolde, D. O., Koeniger, P., Beyer, M., Neukum, C., Groschke, M., Ronelngar, M., Rieckh, H., Vassolo, S., 2019. Soil water balance in the Lake Chad Basin using stable water isotopes and chloride of soil profiles. Isotopes in Environmental and Health Studies , 1-19.

TWB, 2019. Lake Chad Basin Groundwater Modelling. The World Bank. Final report. 197 pp. (unpublished)

Thornthwaite, C. W., Holzman, B., 1939. The determination of evaporation from land and water surfaces. Monthly Weather Review, 67 (I), 4-11.

Tolera, M. B., Chung, I. M., Chang, S. W., 2018. Evaluation of the Climate Forecast System Reanalysis Weather Data for Watershed Modeling in Upper Awash Basin, Ethiopia. Water , 10, 725, doi: $10.3390 /$ w10060725.

UNESCO, 1969. Synthese hydrologique du bassin du lac Tchad. Projet UNESCO/ Fonds special, 1966-1969, Rapport technique presentant les principaux resultats des operations, 217p.

Van de Giesen, N., Hut, R., Selker, J., 2014. The Trans-African Hydro-Meteorological Observatory (TAHMO). Wiley Interdisciplinary Reviews: Water , 1(4), 341-348.

Velpuri, N. M., Senay, G. B., 2013. Analysis of long-term trends (1950-2009) in precipitation, runoff and runoff coefficient in major urban watersheds in the United States. Environmental Research Letter , 8, 024020, doi: 10.1088/1748-9326/8/2/024020.

Vicat, J. P., Pouclet, A., Bellion, Y., Doumnang, J., 2002. Les rhyolites hyperalcalines (pantellerites) du lac Tchad. Composition et signification tectonomagmatique The peralkaline rhyolites (pantellerites) of the Lake Chad. Composition and tectonomagmatic significance. Comptes Rendus Geoscience, 334, 885-891.

Wagner, P. D., Fiener, P., Wilken, F., Kumar, S., Schneider, K., 2012. Comparison and evaluation of spatial interpolation schemes for daily rainfall in data scarce regions. Journal of Hydrology , 464-465, 388-400.

Walker, D., Parkin, G., Schmitte, P., Gowing, J., Tilahun, S. A., Haile, A. T., Yimam, A. Y., 2019. Insights from a multi-method recharge estimation comparison study. Groundwater , 57(2), 245-258.

Wu, J., Zhang, R., Yang, J. Z., 1996. Analysis of rainfall-recharge relationships. Journal of Hydrology , 177(1-2), 143-160.

Young, M. P., Williams, C. J. R., Chiu, C., Maidment, R. I., 2014. Investigation of discrepancies in satellite rainfall estimates over Ethiopia. American Meteorological Society, doi: 10.1175/JHM-D-13-0111.1. 

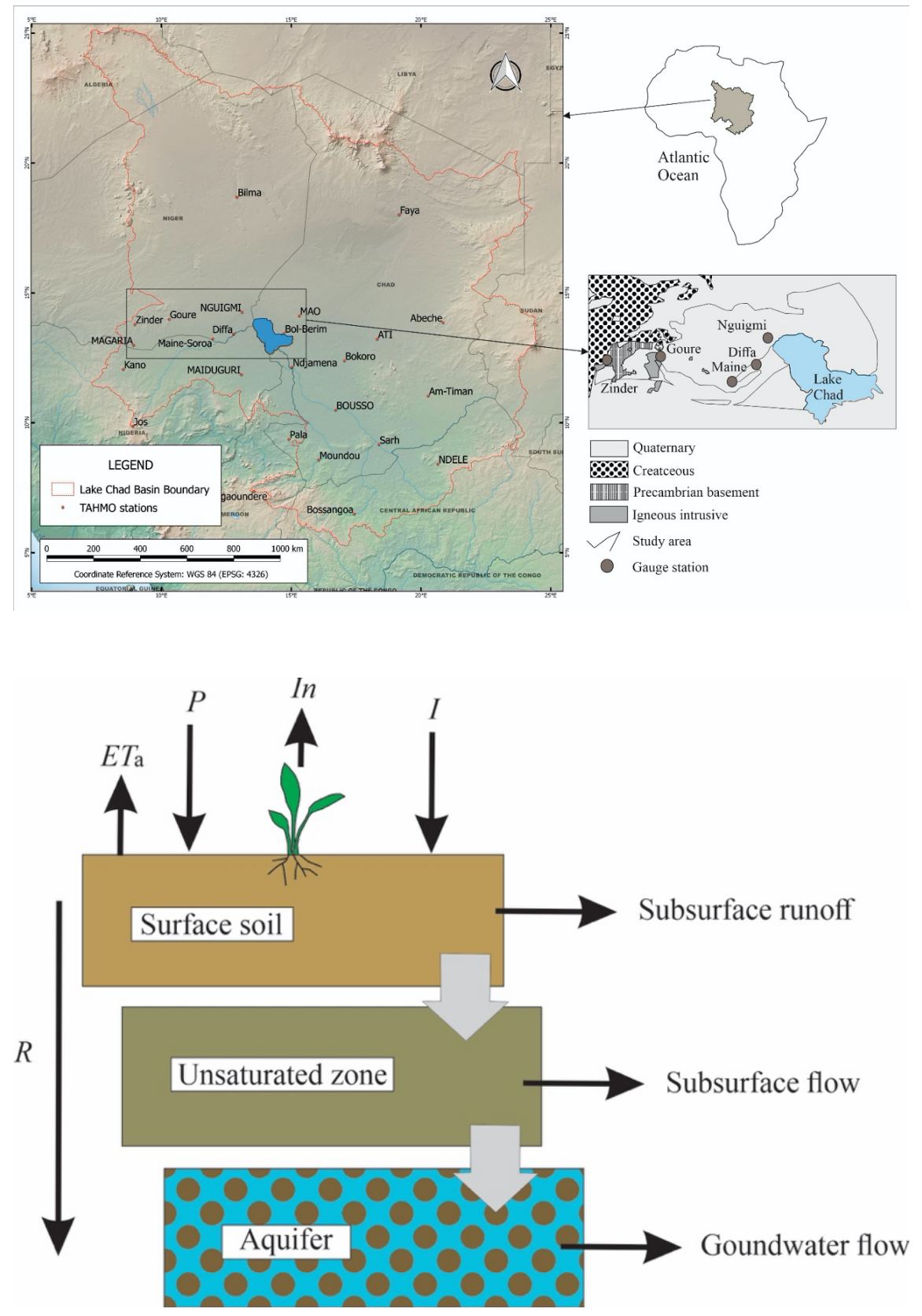

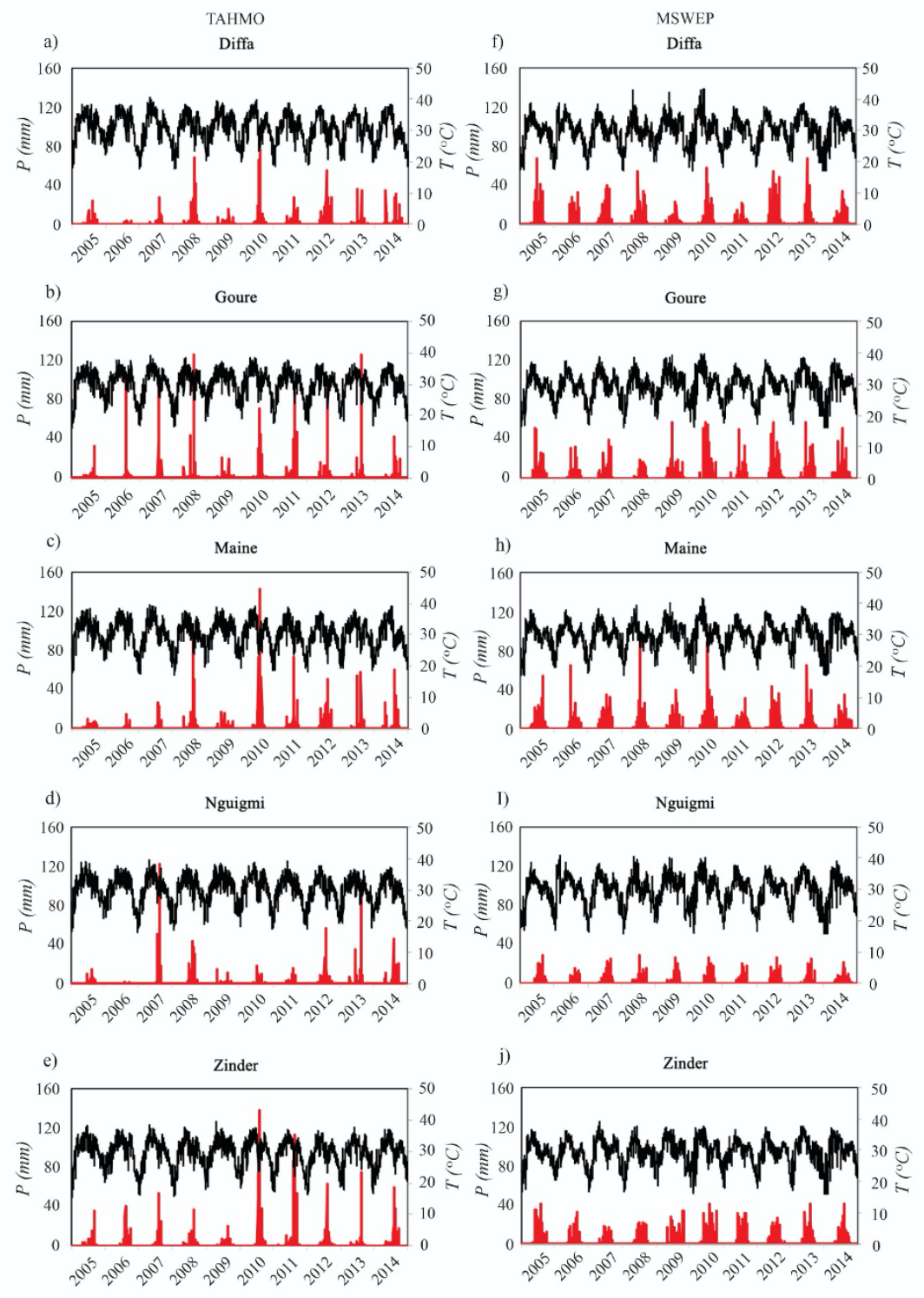

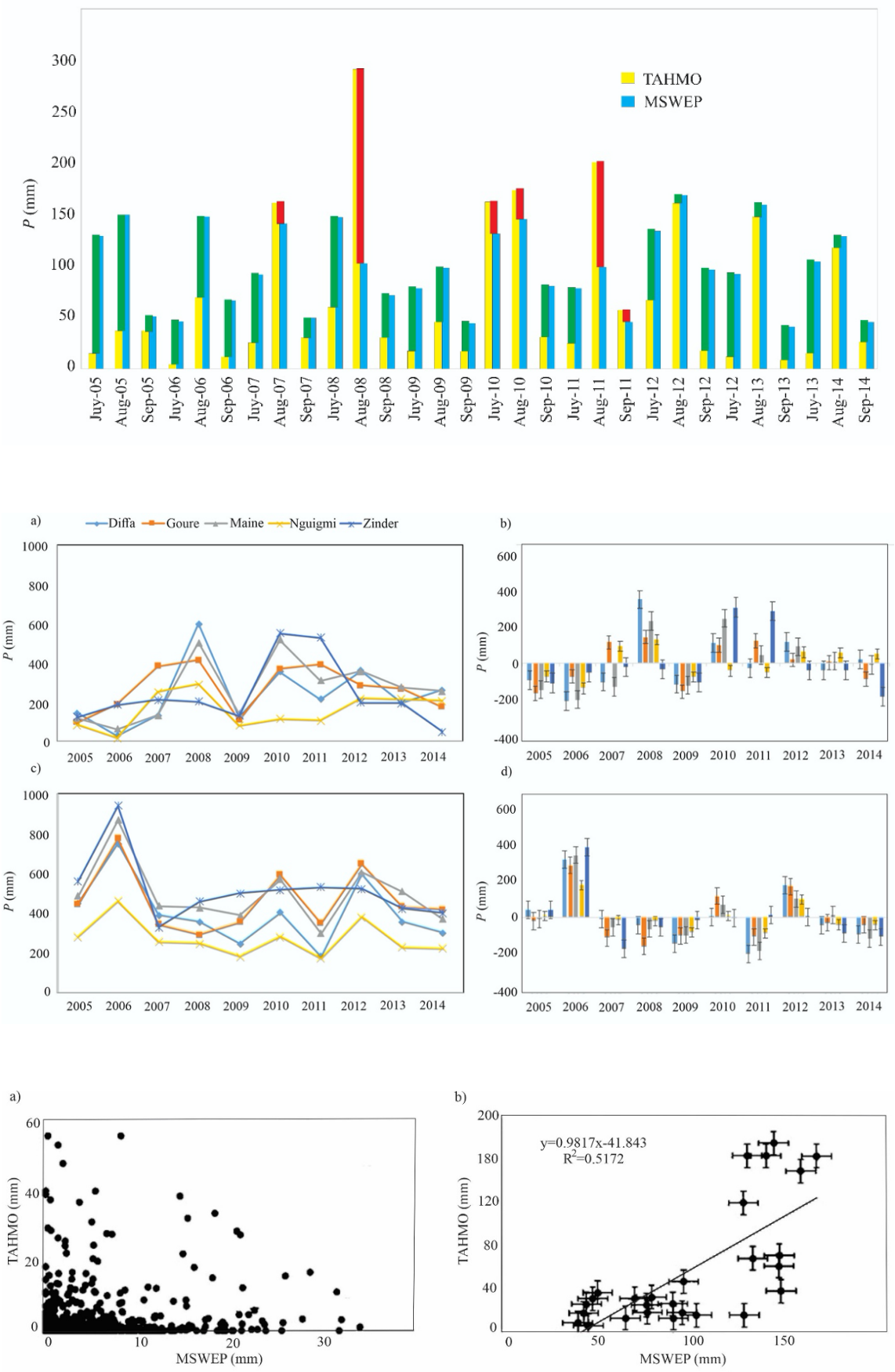
a)

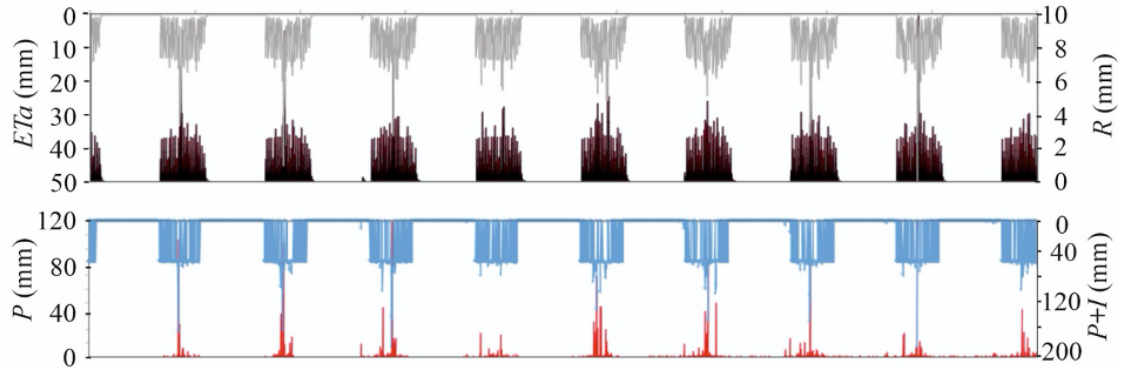

b)
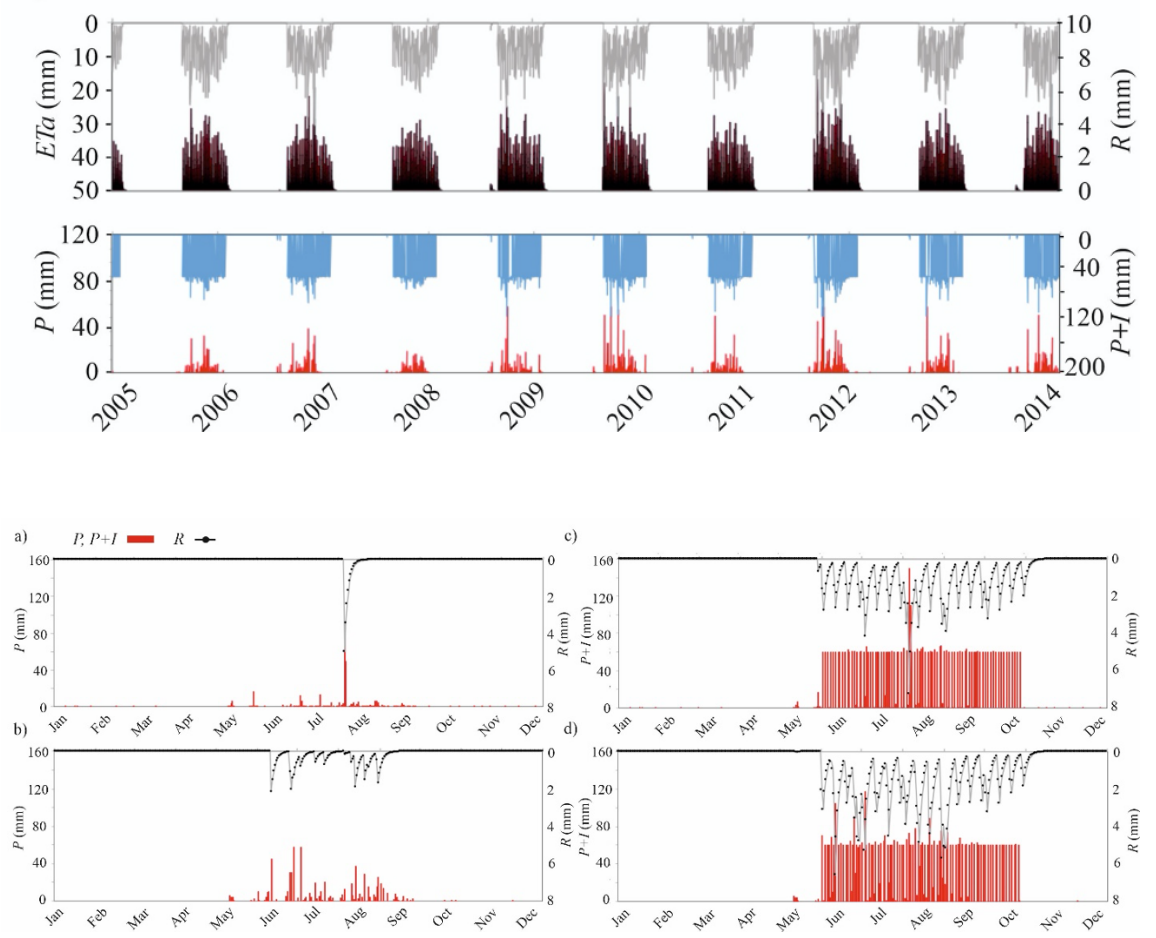
a)

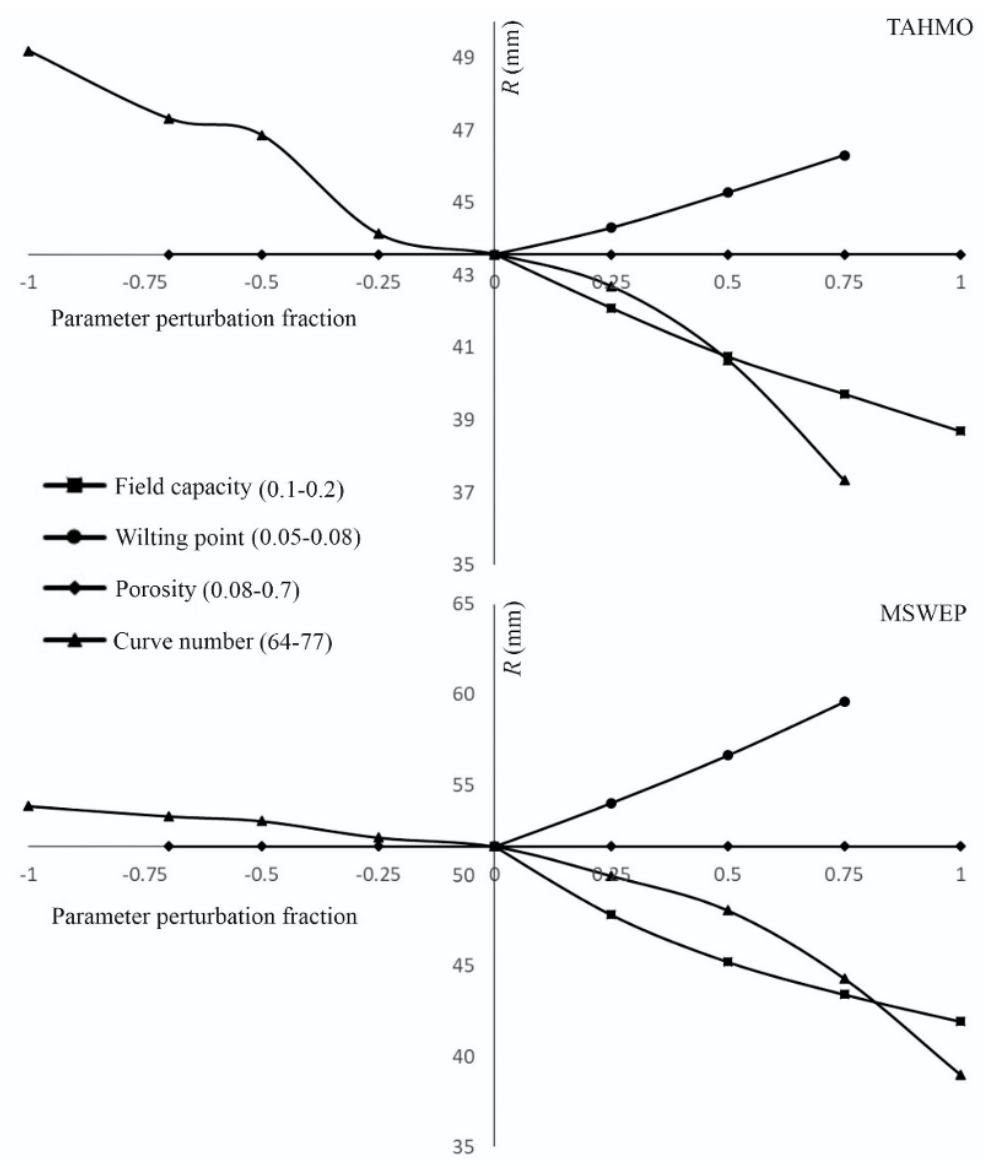

\section{Hosted file}

Table1.docx available at https://authorea.com/users/319867/articles/449563-assessment-ofsatellite-based-approach-for-the-groundwater-recharge-estimation-in-arid-regions 